Vol. 7 (1998): 297-314.

\title{
Agricultural phosphorus and water quality: sources, transport and management
}

\author{
Andrew Sharpley, William Gburek \\ USDA-ARS, Pasture Systems and Watershed Management Research Laboratory, Curtin Road, \\ University Park, Pennsylvania 16802-3702,USA, e-mail: ans3@psu.edu \\ Louise Heathwaite \\ Department of Geography, University of Sheffield, Winter Street, Sheffield, S10 2TN, United Kingdom
}

\begin{abstract}
Freshwater eutrophication is usually controlled by inputs of phosphorus (P). To identify critical sources of $\mathrm{P}$ export from agricultural catchments we investigated hydrological and chemical factors controlling P export from a mixed land use (30\% wooded, $50 \%$ cultivated, $20 \%$ pasture) 39.5 -ha catchment in east-central Pennsylvania, USA. Mehlich-3 extractable soil P, determined on a 30-m grid over the catchment, ranged from 7 to $788 \mathrm{mg} \mathrm{kg}^{-1}$. Generally, soils in wooded areas had low Mehlich-3 P $(<30$ $\mathrm{mg} \mathrm{kg}^{-1}$ ), grazed pasture had Mehlich-3 P values between 100 and $200 \mathrm{mg} \mathrm{kg}^{-1}$, and cropped fields receiving manure and fertiliser applications were in most cases above $200 \mathrm{mg} \mathrm{kg}^{-1}$. Average $\mathrm{P}$ concentrations for ten storms during 1996 decreased 50\% downstream from segment 4 to segment 1 (catchment outlet). Flow-weighted streamflow P concentrations were more closely related to the nearstream (within $60 \mathrm{~m}$ ) than whole catchment distribution of high-P soils. This suggests that nearstream surface runoff and soil $\mathrm{P}$ are controlling $\mathrm{P}$ export from the catchment. Remedial measures should be targeted to these critical P source areas in a catchment. Measures include source (fertiliser and manure application) and transport management (reduce surface runoff and erosion).
\end{abstract}

Key words: animal manure, catchments, critical source areas, drainflow, erosion, fertiliser, leaching, macropores, nonpoint source pollution, remediation, surface runoff, subsurface flow

\section{Introduction}

Agricultural management and catchment characteristics in the Chesapeake Bay Basin (on the northeastern USA coast) are similar to those in Finland and justify their joint assessment in this paper. Compared with other enclosed seas, the
Chesapeake Bay has an appreciably larger catchment area relative to water stored in the Bay $\left(2410 \mathrm{~km}^{2} \mathrm{~km}^{-3}\right.$; Fig. 1). The Gulf of Finland and Bothnian Bay, which both receive drainage from Finland, have the next highest ratios (380 and $180 \mathrm{~km}^{2} \mathrm{~km}^{-3}$, respectively).

Fertiliser use in both the Chesapeake Bay Basin and Finland has declined in the last 5 years, 
Seminar in honour of the 100th anniversary of MTT

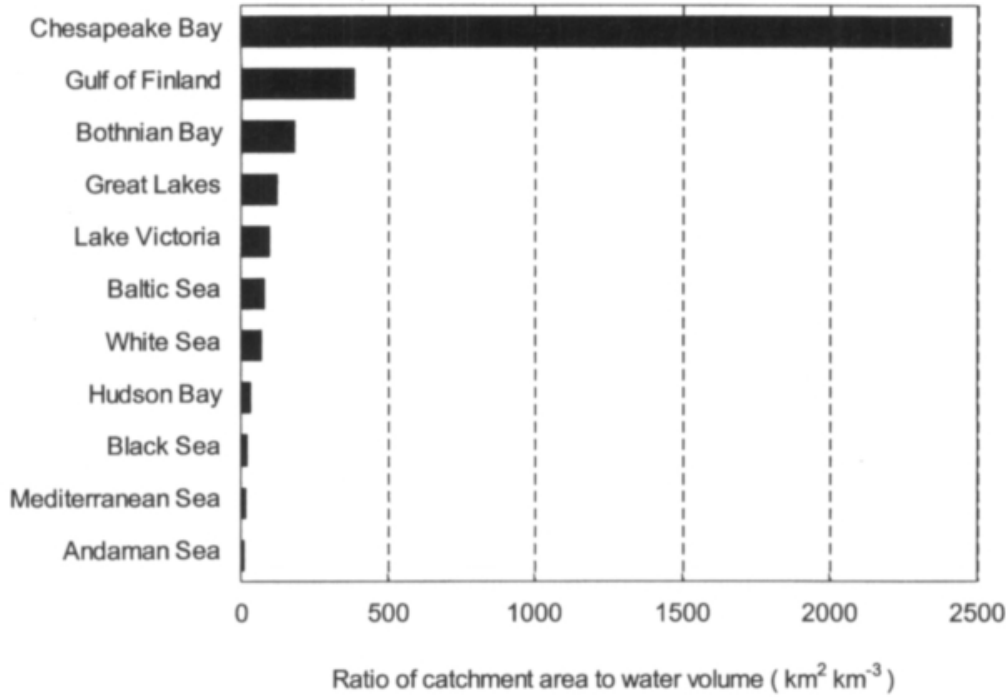

Fig. 1. Ratio of catchment area to volume of water in several major lakes, bays and seas of the world. but the growth and concentration of livestock operations has the potential to produce large amounts of manure and excreted nutrients in localised areas. In many areas, there is an insufficient land base available for efficient utilisation of nutrients in manure, resulting in large localised nutrient surpluses. In both areas, the more intensive agriculture tends to be located near main tributaries and water bodies, with forests generally occupying the outer perimeters of the catchments. Thus, agricultural management has the potential to have a large impact on the quality of waters associated with the Chesapeake Bay Basin and Finland.

Eutrophication has been identified as the main problem in surface waters having impaired water quality in Finland, UK and USA (HELCOM 1993, Ministry of Agriculture, Fisheries and Food 1991, USEPA 1996). Eutrophication restricts water use for fisheries, recreation, industry and drinking due to the increased growth of undesirable algae and aquatic weeds and oxygen shortages caused by their senescence and decomposition. Associated periodic surface blooms of cyanobacteria occur in drinking water supplies throughout the world and may pose a serious health hazard to livestock and humans (Kotak et al. 1993, Lawton and Codd 1991). Eutrophication also causes the loss of crucial habitats including aquatic plant beds in fresh and marine waters and coral reefs of tropical coasts. Recent outbreaks of the dinoflagellate Pfiesteria piscicida in the eastern USA, in Chesapeake Bay tributaries in particular, have been linked to excess nutrients in affected waters. Neurological damage in people exposed to the highly toxic volatile chemical produced by this dinoflagellate has dramatically increased public awareness of eutrophication and the need for solutions. This need is even greater when one realises that by the time these impacts are manifest, remedial strategies are often difficult and expensive to implement, they cross political and regional boundaries, and it can be several years before an improvement in water quality occurs.

Eutrophication of most freshwater around the world is accelerated by $\mathrm{P}$ inputs (Kauppi et al. 1993, Sharpley et al. 1994, Schindler 1977). Although nitrogen $(\mathrm{N})$ and carbon $(\mathrm{C})$ are essential to the growth of aquatic biota, most attention has focused on $\mathrm{P}$ inputs because of the difficulty in controlling the exchange of $\mathrm{N}$ and $\mathrm{C}$ between the atmosphere and water, and fixation of atmospheric $\mathrm{N}$ by some blue-green algae. Thus, $\mathrm{P}$ is often the limiting element and its control is of prime importance in reducing the accelerated eutrophication of fresh waters. As salinity increases, $\mathrm{N}$ generally becomes the ele- 


\section{AGRICULTURAL AND FOOD SCIENCE IN FINLAND}

Vol. 7 (1998): 297-314.

ment controlling aquatic productivity. This is true for both the Chesapeake Bay and Finnish coastal waters, where $\mathrm{P}$ tends to be the limiting nutrient in the upper fresh and brackish water reaches, while $\mathrm{N}$ is limiting in tidal saline waters (Rekolainen 1993, Thomann and Mueller 1987).

In the Chesapeake Bay, $61 \%$ of $\mathrm{P}$ inputs originate from agricultural nonpoint sources, while they contribute $79 \%$ of P in Finnish coastal waters (Chesapeake Bay Program 1995, Rekolainen et al. 1997). In response, the Finnish government decided in 1988 that agricultural $\mathrm{P}$ inputs to freshwaters should be reduced $30 \%$ by 1995 (Ministry of the Environment 1988). Similarly, a $40 \%$ reduction in $\mathrm{P}$ inputs to Chesapeake Bay has been mandated by the year 2000 (Chesapeake Bay Program 1995). Greater than expected reductions in $\mathrm{P}$ discharges from wastewater treatment plants have occurred over the last 15 years (Chesapeake Bay Program 1995, Rekolainen et al. 1992). Even so, water quality problems remained. As further point source controls become less cost-effective, more attention is being directed towards implementing nutrient management plans and farm conservation practices to reduce $\mathrm{P}$ inputs from upstream sources. Wholesale change to current systems could have severe socio-economic impact in rural areas. Therefore, measures are needed which maximise environmental benefit while minimising economic hardship to farmers and the wider community. Thus, there is a need to understand the controlling processes by which $\mathrm{P}$ gets from its source in a catchment to water, and the impact of land management on these processes, in order to design, target and implement effective remedial strategies.

\section{Background}

\section{Sources}

The rapid growth and intensification of the livestock industry in certain areas of the USA, UK and Europe, has created national and regional imbalances in system inputs and outputs of P (Kronvang and Svendsen 1991, Isermann 1991, Withers 1996). On average, only $30 \%$ of the fertiliser and feed input to farming systems is output in crop and livestock produce. Thus, when averaged over the total utilisable agricultural land area in the USA, an annual P surplus of 26 $\mathrm{kg} \mathrm{ha}^{-1}$ exists (National Research Council 1993). The annual P surplus in the UK is around $10 \mathrm{~kg}$ $\mathrm{ha}^{-1}$ (Withers 1998). During the 1980s, there was an annual net $\mathrm{P}$ input in Finland of about $25 \mathrm{~kg}$ ha $^{-1}$ (Rekolainen et al. 1992). Although fertiliser $\mathrm{P}$ applications have declined in the $1990 \mathrm{~s}$, there has been a substantial accumulation of $\mathrm{P}$ in the fields of many farms (Rekolainen 1997).

Prior to World War II, farming communities tended to be self-sufficient in that enough feed was produced locally and recycled to meet livestock requirements. As a result, a sustainable food chain tended to exist. After World War II, increased fertiliser use in crop production fragmented farming systems, creating specialised crop and livestock operations that efficiently coexist in different regions within and among countries. By 1995, over half the corn grain produced in the USA cornbelt was exported as animal feed, while states in the eastern USA imported $83 \%$ of their grain for confined livestock operations (Lanyon and Thompson 1996). In fact, less than $30 \%$ of the grain produced on farms today is fed on the farm where it is grown (USDA 1989).

The addition of more $\mathrm{P}$ to an area than is removed in crop harvest for several years can increase soil test P (Fig. 2). As manure application rate recommendations are routinely based on their $\mathrm{N}$ content and crop $\mathrm{N}$ requirement to minimise the purchase of commercial fertilizer $\mathrm{N}$ and risk of nitrate leaching, the main result of this imbalance has been an increase in soil test $\mathrm{P}$. In 1989, several state soil test laboratories reported the majority of soils analysed had soil test $\mathrm{P}$ levels in the high or very high categories which require little or no $\mathrm{P}$ fertilisation (Fig. 3). However, within states, distinct areas of general $\mathrm{P}$ deficit and surplus can also exist. For example, 


\section{AGRICULTURAL AND FOOD SCIENCE IN FINLAND}

\section{Seminar in honour of the 100th anniversary of MTT}

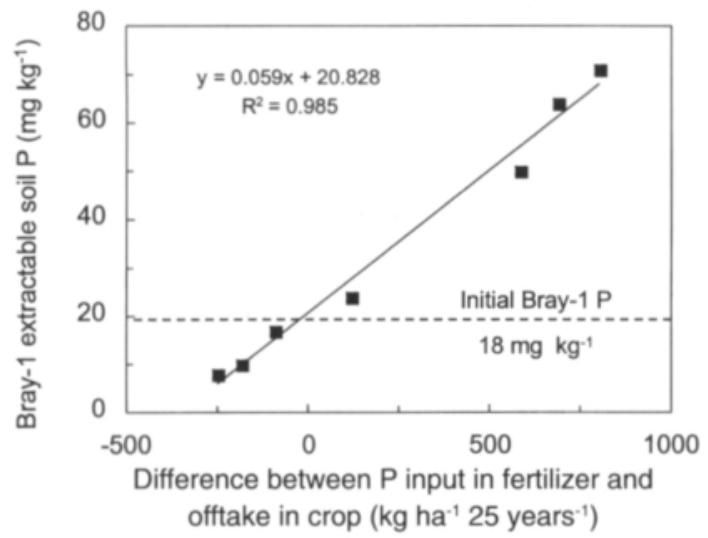

Fig. 2. Bray-1 extractable $P$ content of the surface $(0-$ $15 \mathrm{~cm}$ ) of a Raub silt loam in Indiana as a function of the difference between $P$ input as fertiliser and output in harvested crop (adapted from Barber 1979). soil test summaries for Delaware and Pennsylvania indicate the magnitude and localisation of high soil test $\mathrm{P}$ levels that can occur in areas dominated by intensive livestock production (Fig. 3). In Lancaster County Pennsylvania, where agriculture is dominated by livestock and poultry production, $77 \%$ of soils were rated as optimum or above ( $>51 \mathrm{mg} \mathrm{P} \mathrm{kg}^{-1}$; as Mehlich-3 test P) in 1996; nearby Adams County, with orchard and crop production, was dominated (70\%) by low and medium soil test $\mathrm{P}\left(<50 \mathrm{mg} \mathrm{P} \mathrm{kg}^{-1}\right.$; Fig. 3).

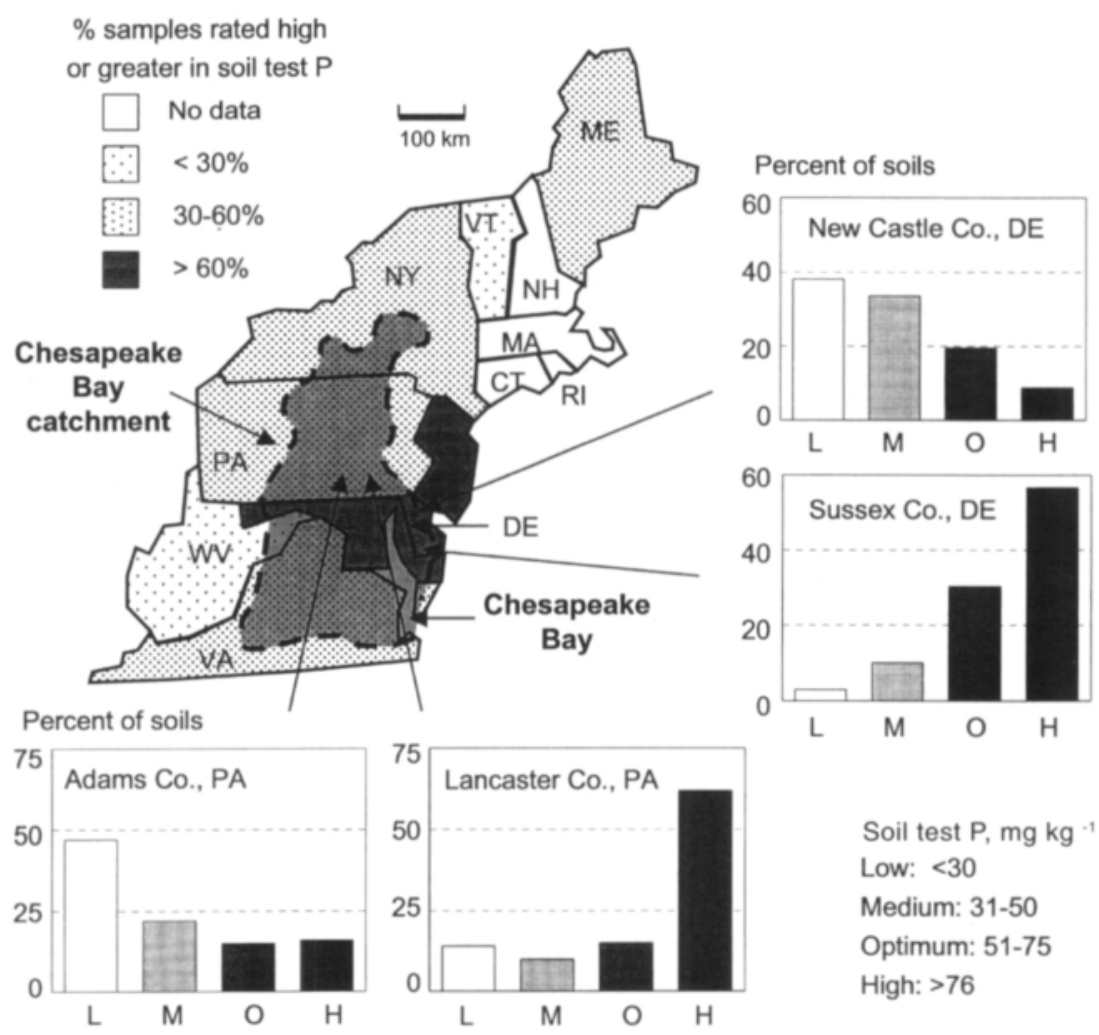

Fig. 3 Percent of soils testing high or above for P in 1989 for the Northeast USA. Also shown is percent of soils rated as low, medium, optimum or high from 1995 soil test summaries for Delaware (DE; Mehlich-1) and Pennsylvania (PA; Mehlich-3) counties with little animal production (New Castle and Adams Co.) and with concentration of livestock production (Sussex and Lancaster Co.). 
Vol. 7 (1998): 297-314.

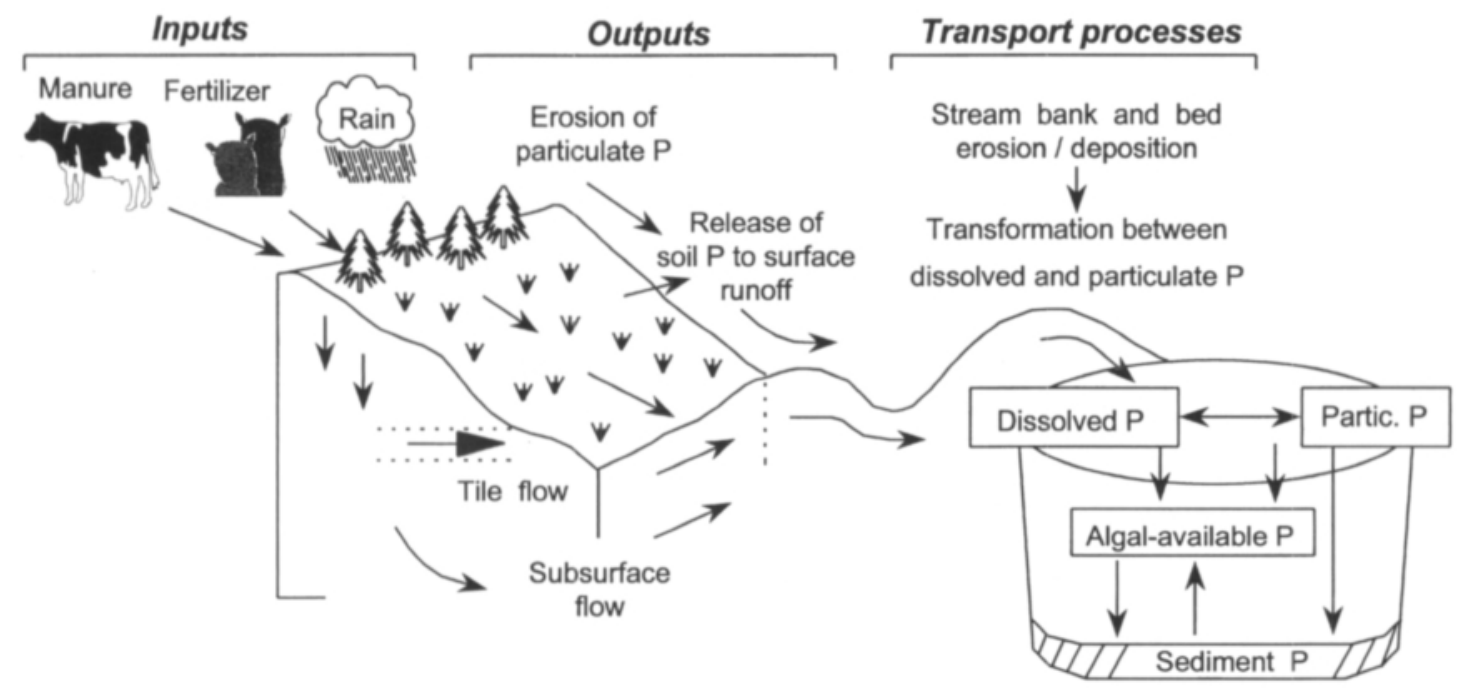

Fig. 4. Inputs, outputs and processes important to transport of $\mathrm{P}$ to surface waters in agricultural ecosystems.

\section{Transport}

The loss of $\mathrm{P}$ in surface runoff occurs in sediment-bound and dissolved forms (Fig. 4). Sediment $\mathrm{P}$ includes $\mathrm{P}$ associated with soil particles and organic matter eroded during flow events and constitutes the major proportion of $\mathrm{P}$ transported from most cultivated land (60-90\%; Pietiläinen and Rekolainen 1991, Sharpley et al. 1994). Surface runoff from grass, forest land or nonerosive soils carries little sediment and is, therefore, generally dominated by dissolved P (DP), although P transport attached to colloidal material may be important (Haygarth and Jarvis 1997, Heathwaite et al. in press). While DP is, for the most part, immediately available for biological uptake, sediment P can be a long-term source of P for aquatic biota (Ekholm 1994, Krogstad and Lovstad 1991, Sharpley 1993). The bioavailability of sediment $\mathrm{P}$ ranges from $5 \%$ to $90 \%$ depending on the nature of the eroding soil and receiving waters (Boström et al. 1988, Rekolainen et al. 1997).

Loss of P from land surface to stream is controlled primarily by the interaction of $\mathrm{P}$ "source" factors (functions of soil, crop and management) with its "transport" factors (surface runoff, ero- sion, subsurface flow and channel processes) (Fig. 4). As the sources of particulate $\mathrm{P}$ in streams include eroding surface soil, streambanks and channel beds, processes determining soil erosion also control particulate P transport. The exception is particulate $\mathrm{P}$ transport in macropores and drainflow where colloidal P transport may be important (Dils and Heathwaite 1996). In general, the $\mathrm{P}$ content and reactivity of eroded particulate material are greater than those of source soil, due to preferential transport of finer material $(<2 \mu \mathrm{m})$. The transport of DP in surface runoff is initiated by the desorption, dissolution and extraction of $\mathrm{P}$ from soil and plant material. These processes occur as a portion of rainfall interacts with a thin layer of surface soil (1 to $5 \mathrm{~cm}$ ) before leaving the field as surface runoff (Sharpley 1985). Although this depth is difficult to quantify in the field, it is expected to be highly dynamic due to variations in rainfall intensity, soil tilth and vegetative cover.

Several studies have reported that the loss of DP in surface runoff is dependent on the soil P content of surface soil (Fig. 5), but the specific DP - soil P relationship varies with management and soil type (Sharpley et al. 1996, Sibbesen and Sharpley 1997, Yli-Halla et al. 1995). Regres- 

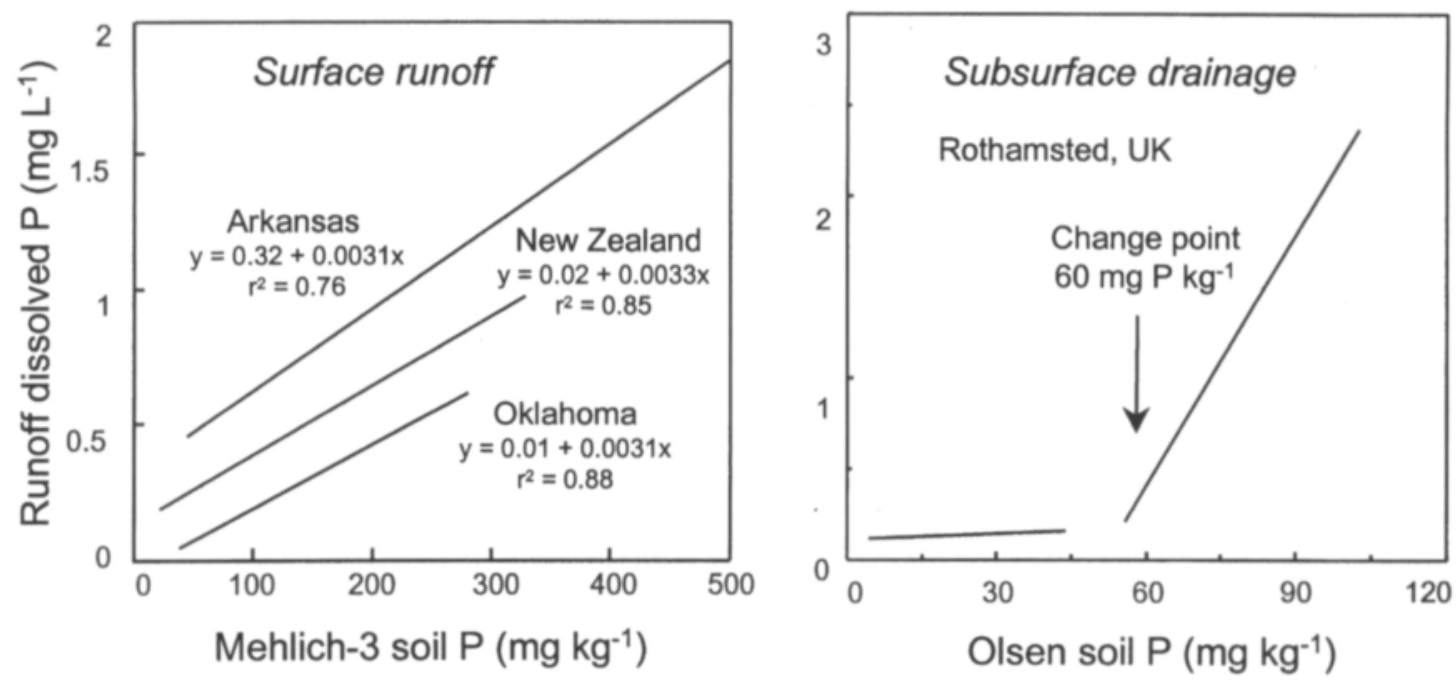

Fig. 5. Effect of soil P on dissolved P concentration of surface runoff from several pasture catchments (adapted from Sharpley et al. 1996) and subsurface drainage from arable Broadbalk fields at Rothamsted, UK (adapted from Heckrath et al. 1995).

sion slopes tend to be lower for grass than for cultivated land, but values are too variable to allow use of a single or average relationship for recommending $\mathrm{P}$ amendments based on water quality criteria. Clearly, several soil and land management factors will influence the relationship between DP in surface runoff and soil P.

The $\mathrm{P}$ content of water percolating through the soil profile is generally lower than for surface runoff, and will decrease as the degree of soil - water contact increases due to sorption of $\mathrm{P}$ by $\mathrm{P}$-deficient subsoils. While this generalisation is true for matrix flow through soils, macropore or bypass flow, together with $\mathrm{P}$ transport in artificial drains, may show patterns and magnitudes of P loss more similar to that of surface runoff (Dils and Heathwaite 1996, Heathwaite et al. in press). Some soil types are susceptible to $\mathrm{P}$ transport in matrix flow. For example, organic or peaty soils, where organic matter may accelerate the downward movement of $\mathrm{P}$ together with organic acids, $\mathrm{Fe}$ and $\mathrm{Al}$.

Phosphorus is more susceptible to movement through sandy soils with low P sorption capacities and also through soils that have become waterlogged. In total though, the loss of $\mathrm{P}$ in subsurface flow as well as in surface runoff, is linked to soil P concentration (Sharpley et al. 1977), although the nature of the relationship is not always clear owing to the complexity of $\mathrm{P}$ transport pathways (Heathwaite et al. in press). Heckrath et al. (1995) found that above an Olsen $\mathrm{P}$ of $60 \mathrm{mg} \mathrm{kg}^{-1}$ in the plough layer of a silt loam, the DP concentration in drainage water increased dramatically (from 0.15 to $2.75 \mathrm{mg} \mathrm{L}^{-1}$; Fig. 5). They postulated that this level, which is well above that needed by major crops for optimum yield (Ministry of Agriculture, Food and Fisheries 1994), is a critical "change point" above which the potential for $\mathrm{P}$ movement in land drains greatly increases. Similar studies suggest that this change point can vary threefold as a function of site hydrology, relative drainage volumes and soil P sorption-desorption characteristics.

\section{Management}

To date, research and implementation have identified agricultural management practices that minimise $\mathrm{P}$ losses in surface runoff by separate- 
Vol. 7 (1998): 297-314.

ly addressing source and transport factors (Bottcher et al. 1995, Sharpley et al. 1994). These practices include applying $\mathrm{P}$ based on soil test $\mathrm{P}$ recommendations and reducing surface runoff and erosion with cover crops, contour ploughing and conservation tillage. However, implementation of these measures over broad areas of a catchment has not resulted in expected reductions in P export (Meals 1993, Sharpley and Rekolainen 1997). This is due to the fact that in humid climates, surface runoff production is usually generated during limited times from limited source areas within upland catchments. The source areas expand and contract rapidly during a storm as a function of rainfall (intensity and duration) and site characteristics (soil moisture, topography, ground water level) of the catchment (Gburek et al. 1996). For example, more than $75 \%$ of annual surface runoff from catchments in Ohio (Edwards and Owens 1991) and Oklahoma (Smith et al. 1991) occurred in one or two severe storms. Further, these events contributed over $90 \%$ of annual total P (TP) export ( 0.2 and $5.0 \mathrm{~kg} \mathrm{ha}^{-1} \mathrm{yr}^{-1}$, respectively). Also, about $90 \%$ of annual algal-available P (AAP) loss from catchments in Pennsylvania occurred from only $10 \%$ of the land area during a relatively few large storms (Pionke et al. 1997). As a result, overall $\mathrm{P}$ management strategies will reduce $\mathrm{P}$ export most effectively when targeted to the critical source-areas within a catchment that are most vulnerable to $\mathrm{P}$ loss in surface runoff (Heathwaite and Johnes 1996, Heatwole et al. 1987, Prato and Wu 1991).

Consequently, preventing $\mathrm{P}$ loss is now taking on the added dimensions of defining, targeting and remediating at the scale of the critical $P$ source areas, i.e., areas within the catchment where high soil $\mathrm{P}$ levels are coincident with high surface runoff and erosion potentials. Thus, information is needed on the hydrological controls linking spatially variable sources and transport processes that determine P loss from a catchment. This paper presents the results of a study of hydrological and chemical processes defining critical source areas and controlling $\mathrm{P}$ export from a small, upland, agricultural catchment in east-central Pennsylvania by examining flow and $\mathrm{P}$ concentrations in streamflow in light of soil $\mathrm{P}$ distribution over the catchment and potential source areas of storm runoff.

\section{Material and methods}

\section{Study area}

The study was conducted on a 39.5-ha subcatchment (FD-36) of Mahantango Creek which is tributary to the Susquehanna River and ultimately the Chesapeake Bay (Fig. 6). FD-36 is typical of upland agricultural catchments within the nonglaciated, folded and faulted Appalachian Valley and Ridge Physiographic Province. Soils are mostly Berks (Typic Dystrochrepts), Calvin (Typic Dystrochrepts), Hartleton (Typic Hapudults) and Watson (Typic Fragiudults) channery silt loams, with slopes ranging from $1 \%$ to $20 \%$. Climate is temperate and humid, average rainfall is approximately $1100 \mathrm{~mm} \mathrm{yr}^{-1}$ and streamflow about $450 \mathrm{~mm} \mathrm{yr}^{-1}$.

The catchment is of mixed land use, with $50 \%$ in soya bean, wheat or corn, $20 \%$ as pasture, and $30 \%$ wooded. In the last 5 years, cropped land north of the FD-36 stream channel received about $60 \mathrm{~m}^{3} \mathrm{ha}^{-1} \mathrm{yr}^{-1}$ pig slurry in spring and no fertiliser $\mathrm{P}$. This amounts to about $100 \mathrm{~kg} \mathrm{P} \mathrm{ha}^{-1} \mathrm{yr}^{-1}$, assuming a slurry $\mathrm{P}$ content of $1.6 \mathrm{~g} \mathrm{~L}^{-1}$ (Gilbertson et al. 1979). South of the stream channel, approximately $5 \mathrm{Mg} \mathrm{ha}^{-1} \mathrm{yr}^{-1}$ poultry manure was added each spring. This amounts to about $85 \mathrm{~kg} \mathrm{P} \mathrm{ha}^{-1} \mathrm{yr}^{-1}$, assuming a manure $\mathrm{P}$ content of $16.9 \mathrm{~g} \mathrm{~kg}^{-1}$ (Gilbertson et al. 1979). As these application rates were obtained from annual farmer interviews, and the P content of slurry and manure can be variable (Eck and Stewart 1995), estimated manurial inputs of P to FD-36 are approximate. However, the values allow relative comparison of inputs and stream flow export of P for FD-36.

FD-36 was divided into four segments based on topography and drainage patterns derived 


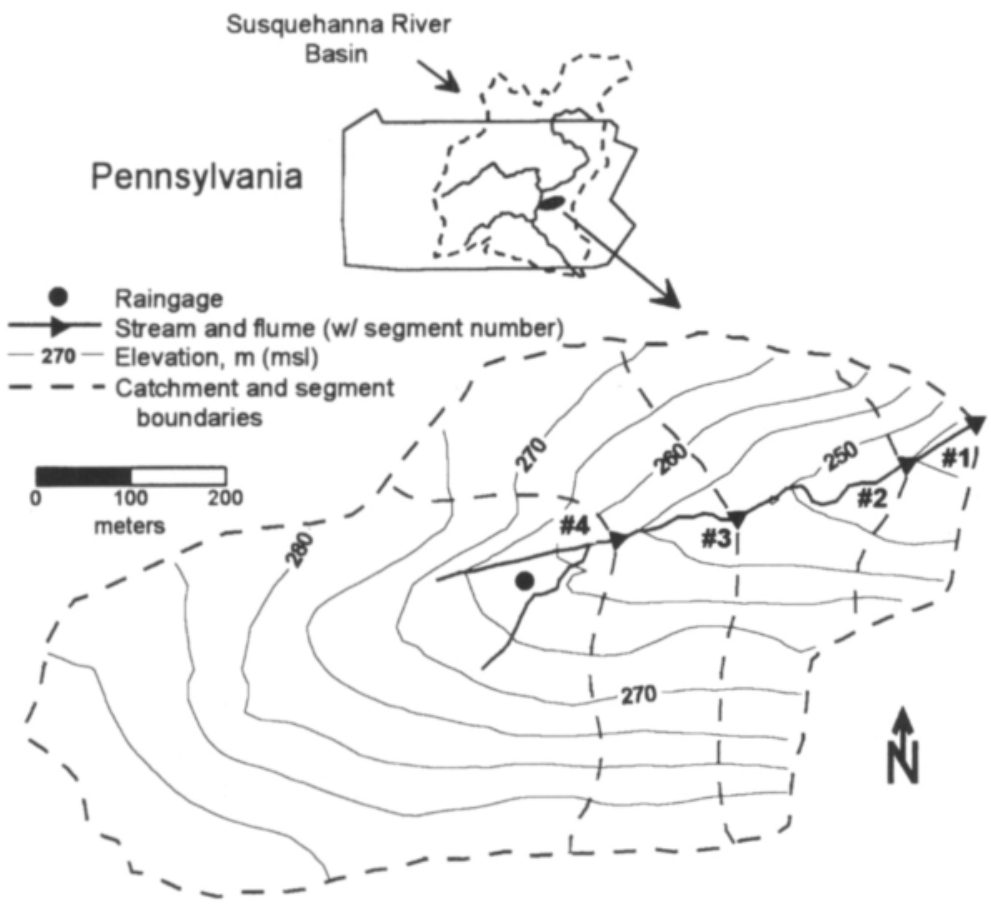

Fig. 6. Location, topography and instrumentation of catchment FD36, Pennsylvania. from a detailed topographic survey and visual reconnaissance (Fig. 6). Beginning in May 1996, streamflow below each segment was continuously monitored using recording $\mathrm{H}$-flumes, and water samples for $\mathrm{P}$ analysis were taken automatically during storm hydrographs at 5- to 120-min intervals using programmable stageactivated samplers. Baseflow samples were taken at each flume at monthly intervals for subsequent $\mathrm{P}$ analysis. All samples were refrigerated at $4 \% \mathrm{C}$ from collection until analysis.

In July 1996, soil samples (0 to 5-cm depth) were collected on a 30 -m grid over the catchment. The samples were air-dried and sieved ( $2 \mathrm{~mm}$ ), and the Mehlich- 3 soil $\mathrm{P}$ concentration was determined.

\section{Hydrograph analysis}

Streamflow hydrographs were separated into baseflow and stormflow components using a semi-log technique (Hall 1968). The width of the near-stream surface runoff-producing zone for each segment and event was estimated from flow increase within each segment using the following procedure. Incremental stormflow volumes were calculated and summed for the total hydrograph to obtain total stormflow volume produced from each event at each flume. Beginning with the most downstream segment (catchment outlet), total stormflow for the next upstream segment was subtracted from the total volume at the flume to obtain stormflow volume produced within each catchment segment. Segment flow volumes were then divided by total rainfall depth and stream length within the segment to approximate the near-stream surface runoff-producing width. This calculation assumes that stormflow comes strictly from rainfall falling on the saturated areas of each segment and that the saturated areas do not expand during the storm event. It was also assumed that the saturated areas were distributed symmetrically about the channel in each catchment segment. 
Vol. 7 (1998): 297-314.

Table 1. Area of each catchment segment, number of soil samples collected on a 30-m grid and Mehlich-3 P contents for FD-36.

\begin{tabular}{|c|c|c|c|c|c|c|c|c|c|c|}
\hline \multirow{2}{*}{$\begin{array}{l}\text { Catchment } \\
\text { segment }\end{array}$} & \multirow[t]{2}{*}{ Area, ha } & \multirow{2}{*}{$\begin{array}{l}\text { Channel } \\
\text { length, } m\end{array}$} & \multirow{2}{*}{$\begin{array}{l}\text { Number of } \\
\text { samples }\end{array}$} & \multicolumn{3}{|c|}{ Mehlich $3 \mathrm{P}, \mathrm{mg} \mathrm{kg}^{-1}$} & \multicolumn{4}{|c|}{ Percent in each category, $\%$} \\
\hline & & & & Mean & Min. & Max. & $<30$ & $30-100$ & $100-200$ & $>200$ \\
\hline 1 & 2.34 & 86 & 26 & 118 & 14 & 404 & 16 & 44 & 9 & 30 \\
\hline 2 & 8.92 & 222 & 99 & 166 & 7 & 788 & 43 & 13 & 6 & 38 \\
\hline 3 & 4.70 & 106 & 52 & 199 & 21 & 449 & 6 & 16 & 39 & 39 \\
\hline 4 & 23.58 & 332 & 262 & 141 & 10 & 775 & 41 & 9 & 21 & 29 \\
\hline Total & 39.54 & 746 & 439 & 168 & 7 & 788 & 34 & 14 & 19 & 33 \\
\hline
\end{tabular}

\section{Phosphorus analyses}

Dissolved P was determined on filtered $(0.45$ $\mu \mathrm{m})$ stream water samples by the molybdenumblue method of Murphy and Riley (1962). The same method was used for TP following digestion of unfiltered surface runoff water with a semimicro Kjeldahl procedure (Bremner and Mulvaney 1982). Algal-available $P$ was determined using Fe-oxide impregnated strips (Sharpley 1993). Five $\mathrm{mL}$ of unfiltered surface runoff (made up to $50 \mathrm{~mL}$ with distilled water) and one Fe-oxide strip were shaken end-over-end for 16 $\mathrm{h}$ at $4^{\circ} \mathrm{C}$. The strip was removed, rinsed free of soil particles, and shaken end-over-end for $1 \mathrm{~h}$ in $1 \mathrm{M} \mathrm{HCl}$ to remove AAP.

Mehlich-3 soil P concentration was determined by extraction of $1 \mathrm{~g}$ soil with $10 \mathrm{~mL}$ of $0.2 M \mathrm{CH}_{3} \mathrm{COOH}, 0.25 M \mathrm{NH}_{4} \mathrm{NO}_{3}, 0.015 M$ $\mathrm{NH}_{4} \mathrm{~F}, 0.013 \mathrm{MNO}_{3}$ and $0.001 M$ EDTA for 5 min (Mehlich 1984). Phosphorus in all filtered and neutralised extracts was determined by the method of Murphy and Riley (1962).

\section{Results and discussion}

\section{Soil $P$ distribution}

On a $30-\mathrm{m}$ grid over the catchment, Mehlich-3 $P$ ranged from 7 to $788 \mathrm{mg} \mathrm{kg}^{-1}$ (Table 1). The Mehlich-3 soil $\mathrm{P}$ values were grouped into four categories based on agronomic and environmen- tal factors: $<30 \mathrm{mg} \mathrm{kg}^{-1}$, crops require additional $\mathrm{P}$ for optimum growth; between 30 and 100 $\mathrm{mg} \mathrm{kg}^{-1}$, there will generally be a crop response to $P$ application but little enrichment of $P$ in surface runoff (probable crop response decreases as Mehlich-3 $\mathrm{P}$ increases from 50 to $100 \mathrm{mg} \mathrm{kg}^{-1}$ ); between 100 and $200 \mathrm{mg} \mathrm{kg}^{-1}$, there will be no response to applied $\mathrm{P}$ while some enrichment of $\mathrm{P}$ in surface runoff may occur; $>200 \mathrm{mg} \mathrm{kg}^{-1}$, levels are considered excessive in terms of crop requirements and enrichment of $\mathrm{P}$ in surface runoff can be expected (Beegle 1996, Sharpley et al. 1996).

The pattern of Mehlich-3 P values over FD36 is generally a function of land use and field boundaries within the catchment (Fig. 7). Soils in wooded areas have low values of Mehlich-3 P $\left(<30 \mathrm{mg} \mathrm{kg}^{-1}\right)$, grazed pastures have values between 100 and $200 \mathrm{mg} \mathrm{kg}^{-1}$, and cropped fields receiving manure and fertiliser applications are, in most cases, above $200 \mathrm{mg} \mathrm{kg}^{-1}$. Based on the grid sampling, $52 \%$ of the soils on FD-36 have Mehlich-3 P concentrations in excess of levels sufficient for optimum crop growth $(>100 \mathrm{mg}$ $\mathrm{kg}^{-1}$ ), with $33 \%$ above $200 \mathrm{mg} \mathrm{kg}^{-1}$ (Table 1). Of the remaining $48 \%$ of soils, $\mathrm{P}$ application would be recommended on only $14 \%$ for optimum crop production (30-100 $\left.\mathrm{mg} \mathrm{kg}^{-1}\right)$ as the other $34 \%$ are mostly wooded $\left(<30 \mathrm{mg} \mathrm{kg}^{-1}\right)$ (Table 1$)$.

\section{Streamflow $P$}

Average flow-weighted DP, AAP and TP concentrations in streamflow leaving each of the four catchment segments were determined for each 


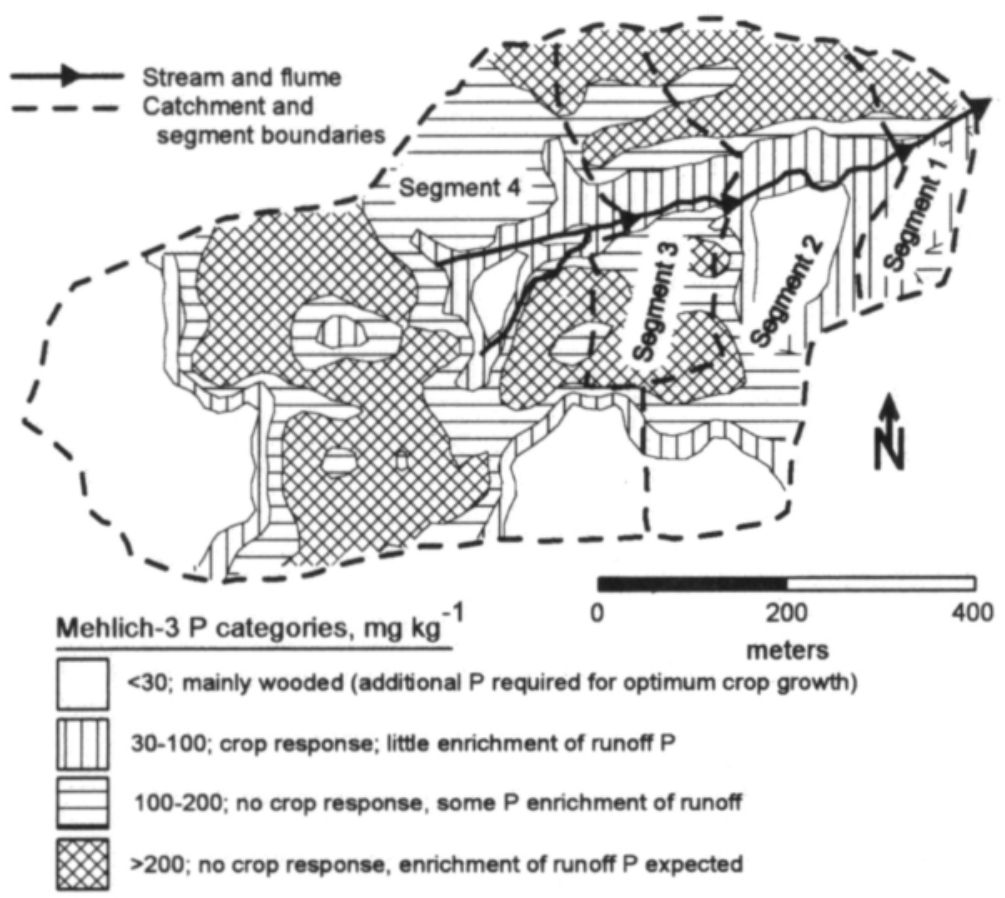

Fig. 7. Mehlich-3 P distribution over FD-36; flume locations and segment numbers are also shown. storm event from August to the beginning of November 1996 (Table 2). For all events, average $\mathrm{P}$ concentration decreased downstream from segment 4 to segment 1 (the catchment outlet). On average, DP concentration decreased by $60 \%$, AAP by $56 \%$ and TP by $59 \%$. Also, DP comprised $54 \%$ and $60 \%$ of AAP at segments 4 and 1 , respectively, while AAP was $53 \%$ of TP at segment 4 and $49 \%$ at segment 1 . Although the concentration decrease and distribution of DP and AAP were similar between segment 4 and the catchment outlet, the relative importance of controlling hydrological or chemical processes will likely vary along the stream channel. These processes may include dilution by input of subsurface flow to the stream channel, deposition and resuspension of particulate material and associated P, sorption of DP by suspended sediment and channel bank/bed material, and a differential contribution of $P$ in surface runoff from spatially variable areas of surface runoff production and high soil $\mathrm{P}$.
From the above analysis, it is apparent that the distribution of P forms (DP, AAP and TP) in streamflow changed little during transport along the channel. Dissolved P averaged 29\% of TP and AAP 50\% of TP at each segment flume (Table 2). Also, the decline in $P$ concentration from segment 4 to segment 1 (watershed outlet) was similar for DP, AAP and TP (56\% to $60 \%)$. This suggests that channel processes may be relatively unimportant compared with variations in source area input among segments.

While we are continuing this investigation of the controls on processes of $\mathrm{P}$ loss, comparison of stormflow P concentration and soil P distribution patterns over the catchment may provide insight into the linkages between high $\mathrm{P}$ soils and surface runoff-producing areas. Estimated widths of saturated areas adjacent to the stream channel ranged from $<1$ to $62 \mathrm{~m}$ and showed a general increase downstream from segment 4 to $1(\mathrm{P}<0.5$, Table 3$)$.

Assuming most of the stormflow increase 


\section{AGRICULTURAL AND FOOD SCIENCE IN FINLAND}

Vol. 7 (1998): 297-314.

Table 2. Mean flow-weighted concentration of dissolved, algal-available and total $\mathrm{P}$ in streamflow leaving each segment during ten flow events in 1996.

\begin{tabular}{|c|c|c|c|c|}
\hline \multirow{2}{*}{$\begin{array}{l}\text { Flow } \\
\text { Event } \\
\end{array}$} & \multicolumn{4}{|c|}{ Catchment segment } \\
\hline & 1 & 2 & 3 & 4 \\
\hline & & $-I$ & & \\
\hline 9 August & 0.019 & 0.036 & 0.050 & 0.097 \\
\hline 6 September & 0.027 & 0.038 & 0.070 & 0.088 \\
\hline 7 September & 0.020 & 0.024 & 0.039 & 0.046 \\
\hline 13 September & 0.060 & 0.073 & 0.119 & 0.148 \\
\hline 16 September & 0.104 & 0.137 & 0.163 & 0.202 \\
\hline 17 September & 0.074 & 0.080 & 0.099 & 0.111 \\
\hline 28 September & 0.066 & 0.082 & 0.103 & 0.119 \\
\hline 9 October & 0.065 & 0.123 & 0.172 & 0.206 \\
\hline 18 October & 0.448 & 0.511 & 0.743 & 0.731 \\
\hline 8 November & 0.195 & 0.253 & 0.322 & 0.392 \\
\hline \multirow[t]{2}{*}{ Average } & 0.046 & 0.062 & 0.088 & 0.116 \\
\hline & \multicolumn{4}{|c|}{ - Algal-available $P, \mathrm{mg} \mathrm{L}^{-l}$} \\
\hline 9 August & 0.044 & 0.060 & 0.088 & 0.126 \\
\hline 6 September & 0.050 & 0.071 & 0.113 & 0.175 \\
\hline 7 September & 0.043 & 0.057 & 0.122 & 0.144 \\
\hline 13 September & 0.122 & 0.136 & 0.175 & 0.182 \\
\hline 16 September & 0.166 & 0.236 & 0.259 & 0.333 \\
\hline 17 September & 0.105 & 0.122 & 0.156 & 0.165 \\
\hline 28 September & 0.142 & 0.170 & 0.204 & 0.223 \\
\hline 9 October & 0.109 & 0.163 & 0.248 & 0.299 \\
\hline 18 October & 0.608 & 0.670 & 0.980 & 0.923 \\
\hline 8 November & 0.230 & 0.284 & 0.378 & 0.447 \\
\hline Average & 0.085 & 0.112 & 0.151 & 0.192 \\
\hline 9 August & 0.089 & 0.109 & 0.147 & 0.181 \\
\hline 6 September & 0.129 & 0.262 & 0.473 & 0.543 \\
\hline 17 September & 0.114 & 0.156 & 0.268 & 0.334 \\
\hline 13 September & 0.200 & 0.232 & 0.324 & 0.334 \\
\hline 16 September & 0.266 & 0.315 & 0.434 & 0.580 \\
\hline 17 September & 0.198 & 0.230 & 0.312 & 0.347 \\
\hline 28 September & 0.392 & 0.478 & 0.495 & 0.660 \\
\hline 9 October & 0.204 & 0.261 & 0.591 & 0.761 \\
\hline 18 October & 0.708 & 0.776 & 0.998 & 1.238 \\
\hline 8 November & 0.759 & 0.838 & 0.990 & 1.015 \\
\hline Average & 0.160 & 0.215 & 0.329 & 0.394 \\
\hline
\end{tabular}

within segments originates as surface runoff from the near-stream area, the distribution of high Mehlich-3 soil $\mathrm{P}$ in this area and the whole catchment were compared (Fig. 8). On a whole catchment basis, there was little difference among the four catchment segments in the percent of soils $>200 \mathrm{mg} \mathrm{kg}^{-1}$ Mehlich-3 P (29\% to 39\%, Table 1 and Fig. 8). This is the Mehlich-3 P category that is expected to result in enrichment of DP in surface runoff. However, on a near-stream basis, the areal distribution of these high P soils decreased from $50 \%$ in segment 4 to $8 \%$ in segment 1 . Thus, the trend of decreasing stormflow DP concentration downstream was more closely related to 


\section{AGRICULTURAL AND FOOD SCIENCE IN FINLAND}

Seminar in honour of the 100th anniversary of MTT

Table 3. Saturated distance from the stream channel for catchment segments during each flow event in 1996.

\begin{tabular}{|c|c|c|c|c|}
\hline \multirow{2}{*}{$\begin{array}{l}\text { Flow } \\
\text { Event }\end{array}$} & \multicolumn{4}{|c|}{ Catchment segment } \\
\hline & 1 & 2 & 3 & 4 \\
\hline 9 August & 10.4 & 3.2 & 0.6 & 1.9 \\
\hline 6 September & 1.4 & 0.2 & 0.1 & 0.3 \\
\hline 7 September & 5.4 & 0.9 & 0.5 & 1.9 \\
\hline 13 September & 5.0 & 1.0 & 0.6 & 1.0 \\
\hline 16 September & 12.9 & 4.1 & 10.7 & 5.7 \\
\hline 17 September & 17.6 & 5.4 & 14.6 & 5.6 \\
\hline 28 September & 20.1 & 4.2 & 4.7 & 3.8 \\
\hline 9 October & 2.2 & 0.9 & 0.6 & 0.5 \\
\hline 18 October & 54.6 & 36.6 & 62.2 & 25.9 \\
\hline 8 November & 17.0 & 38.7 & 35.9 & 20.4 \\
\hline Average & 14.7 & 9.5 & 13.0 & 6.7 \\
\hline
\end{tabular}

the near-stream distribution of high $\mathrm{P}$ soils in each catchment segment than to the whole catchment (Fig. 8). This integration of hydrological processes and chemical properties of catchment soils suggests that near-stream soil $\mathrm{P}$ concentration has a greater influence on $\mathrm{P}$ export from the catchment than does soil $\mathrm{P}$ concentration at the whole-catchment scale.

These findings have important implications for catchment management of $\mathrm{P}$ from fertiliser or manure applications. For instance, current thinking may set $\mathrm{P}$ management goals based solely on Mehlich-3 P concentrations for soils over the entire catchment (Sharpley et al. 1996). In this case, nearly $80 \%$ of the cropped and pasture soils over FD-36 are sufficiently high in $\mathrm{P}(>100$ $\mathrm{mg} \mathrm{kg}^{-1}$ ) that there would be no crop-yield response to further $\mathrm{P}$ applications. An environmental soil test P level of $200 \mathrm{mg} \mathrm{kg}^{-1}$ Mehlich-3 P has been proposed by several states in the USA as a threshold level above which P enrichment of surface runoff and increase in $\mathrm{P}$ export is like-

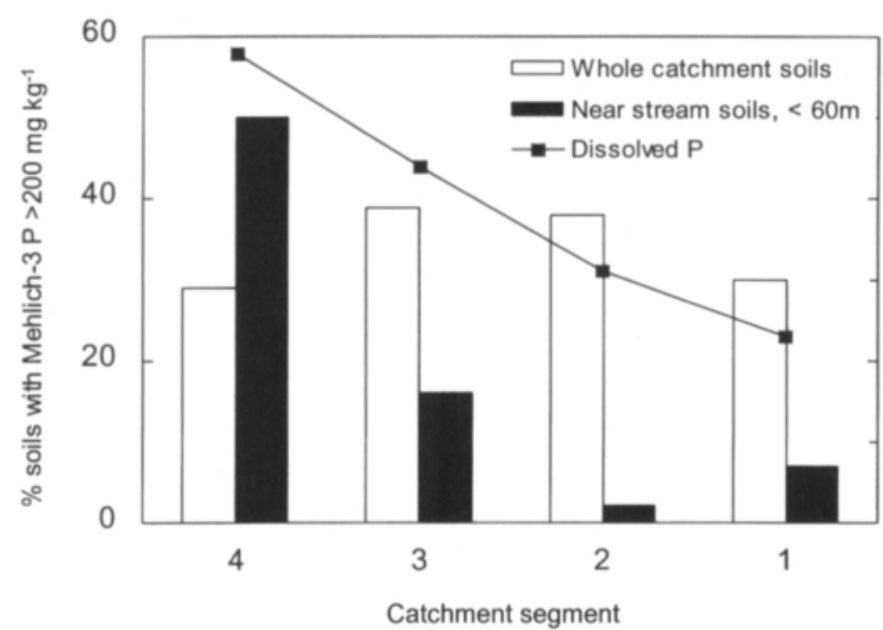


Vol. 7 (1998): 297-314.

ly, indicating $\mathrm{P}$ applications should be more carefully managed in these areas (Sharpley et al. 1996). Based on this, application of $P$ to $63 \%$ of the cropped area of FD-36 would be limited or restricted. Clearly, this would adversely impact those farmers having confined swine and poultry operations on the catchment where produced manures are presently applied.

Alternatively, delineation of surface runoffproducing areas and recognition of the similarity between patterns of $\mathrm{P}$ concentration in streamflow and $\mathrm{P}$ concentration of near-stream soils suggests that $\mathrm{P}$ management goals should focus on the near-stream areas rather than the whole catchment. With this approach, accounting for the interactions among soil $\mathrm{P}$, land use and hydrological characteristics of the catchment, it is possible to better target remedial programs to critical P source areas of the catchment.

\section{Implications for remediation}

Phosphorus export from agriculture may be minimised with source and transport management strategies. Although we know how, and have generally been able to reduce $\mathrm{P}$ transport from tilled land in surface runoff and erosion, less attention has been directed toward other land uses (e.g. grassland) and source management. For example, it is clear from the extent of soils with $\mathrm{P}$ in excess of levels sufficient for optimum crop yields, as in FD-36, that more attention should be paid to avoiding soil $\mathrm{P}$ build-up via $\mathrm{P}$-source management. General remedial measures that minimise P export from agricultural catchments are presented, with reference to results from FD36 , where appropriate.

\section{Source management}

\section{Manures}

Manipulation of dietary P intake by livestock may help reduce regional surpluses of $\mathrm{P}$. Morse et al. (1992) recorded a $17 \%$ reduction in $\mathrm{P}$ excretion when dairy cows reduced their daily $\mathrm{P}$ intake from 82 to $60 \mathrm{~g} \mathrm{day}^{-1}$. In the Netherlands, reductions in concentrate $\mathrm{P}$ are now being implemented to help reduce the amounts of $\mathrm{P}$ excreted to land (Wadman et al. 1987). Enzyme additives for livestock feed that increase P absorption efficiency during digestion and weight gain are also being tested. One example is the use of phytase, an enzyme that enhances the efficiency of $\mathrm{P}$ recovery from phytin in grains fed to poultry. This has the potential to reduce $P$ concentration in poultry manures and litters.

Commercially available manure amendments, such as slaked lime or alum, can reduce $\mathrm{NH}_{3}$ volatilisation and $\mathrm{P}$ solubility of poultry litter by several orders of magnitude (Moore and Miller 1994). Also, the DP concentration of surface runoff from fescue treated with alumamended litter $\left(11 \mathrm{mg} \mathrm{L}^{-1}\right)$ was much lower than from fescue treated with unamended litter ( 83 $\mathrm{mg} \mathrm{L}^{-1}$; Shreve et al. 1995). Perhaps the most important benefit of manure amendments (for both air and water quality), however, will be an increase in the N:P ratio of manure via reduced $\mathrm{N}$ loss from manure by $\mathrm{NH}_{3}$ volatilisation. An increased N:P ratio of manure would better match crop $\mathrm{N}$ and $\mathrm{P}$ requirements. Thus, additions of manure based on crop $\mathrm{N}$ requirements would reduce the $\mathrm{P}$ excess added, thereby minimising potential soil $\mathrm{P}$ accumulations.

Localised surpluses of $\mathrm{P}$ are exacerbated by the fact that manures are rarely transported more than $20 \mathrm{~km}$ from where they are produced. However, mandatory transport of manure from surplus areas to nearby farms where the nutrients are needed faces several significant obstacles. First, it must be shown that the current location is unsuitable, based on soil properties, crop nutrient requirements, topography and hydrology. From European experiences this may be difficult to justify scientifically due to the large temporal and spatial variability in the factors controlling $\mathrm{N}$ and $\mathrm{P}$ mobility in soils and transport to ground or surface waters. Second, in many areas there is no clearly defined legal basis for requiring farmers in one physiographical area to 


\section{AGRICULTURAL AND FOOD SCIENCE IN FINLAND}

\section{Seminar in honour of the 100th anniversary of MTT}

perform management practices that are not required on neighbouring farms. More success with re-distribution of manures is likely to occur when consumers, local governments, the farm community and livestock industry are all involved in setting regional policies.

\section{Soils}

In parts of the world, regional authorities are considering development of recommendations for $\mathrm{P}$ applications based on the potential for $\mathrm{P}$ loss in surface runoff, as well as on crop P requirements. A major difficulty in development of these recommendations has been the identification of threshold levels of soil $\mathrm{P}$ that are likely to result in unacceptable losses of P in surface runoff. Establishing these levels is a controversial process for two reasons. First, the data base relating soil $\mathrm{P}$ levels to surface runoff $\mathrm{P}$ concentration is limited to a few soils and crops, and there is a reluctance to extrapolate data of this type to other regions. Second, the economic implications of establishing soil test P levels which may limit manure applications are significant. In many areas dominated by animal-based agriculture, there simply is no economically viable alternative to land application. Thus, there is a need to assess the validity of using soil test $P$ values as indicators of $P$ loss in surface runoff. In FD-36, for example, manure application to over $60 \%$ of the catchment would be limited by a soil test $P$ threshold of $200 \mathrm{mg} \mathrm{kg}^{-1}$.

Another approach developed in the Netherlands and applicable to subsurface pathways of $P$ transport, determines the potential for DP movement in drainage water by estimating soil $\mathrm{P}$ saturation as the percentage of $\mathrm{P}$ sorption capacity as extractable soil P (Breeuwsma and Silva 1992). This approach is based on the fact that more $\mathrm{P}$ is released from soil to matrix flow or leaching water as $\mathrm{P}$ saturation or amount of $\mathrm{P}$ sorbed increases with $\mathrm{P}$ additions. Soil $\mathrm{P}$ saturation is used in the Netherlands, where farm recommendations for manure management are designed to limit the loss of $\mathrm{P}$ in surface and ground waters. For Dutch soils, a critical P saturation of $25 \%$ has been established as the threshold value above which the potential for $\mathrm{P}$ movement in surface and ground waters becomes unacceptable (Breeuwsma and Silva 1992).

\section{Transport management}

Once water and sediment begin to move over the land surface, taking with them the nutrients originally applied as fertiliser and/or manure, the quantities which reach the stream can be reduced by any feature which slows flow and/or encourages infiltration or sediment trapping. Such measures include terracing, contour tillage, cover crops, buffer strips, riparian zones, and impoundments or small reservoirs. These practices are generally more efficient at reducing particulate $P$ rather than DP. However, such approaches only work where subsurface pathways of $P$ loss are unimportant. Furthermore, by encouraging infiltration of surface runoff, which may be enriched with $\mathrm{P}$, the problem is simply translated from surface delivery to subsurface delivery. While uptake by plant roots and adsorption onto soil particles may delay the delivery of $P$ to surface waters, such mechanisms may be ineffective in soils with a high hydraulic conductivity (e.g. sands) or where macropore or drainflow is important (Heathwaite 1997).

Usually, farm $\mathrm{N}$ inputs can be more easily balanced with plant uptake than can $\mathrm{P}$, particularly where confined animal operations exist. In the past, separate strategies for $\mathrm{N}$ and $\mathrm{P}$ have been developed and implemented at farm or catchment scales. Because of differing chemistry and flow pathways of $\mathrm{N}$ and $\mathrm{P}$ in soil and through the catchment, these narrowly targeted strategies often are in conflict and lead to compromised water quality remediations. For example, basing manure application on crop $\mathrm{N}$ requirements to minimise nitrate leaching to ground water increases soil $\mathrm{P}$ and enhances potential $\mathrm{P}$ surface runoff losses. In contrast, reducing surface runoff losses of P via conservation tillage can enhance nitrate leaching.

For P, a primary strategy is to minimise surface runoff and particulate transport. In most 


\section{AGRICULTURAL AND FOOD SCIENCE IN FINLAND}

Vol. 7 (1998): 297-314.

cases the necessary measures - soil cover as plants or crop residues, cultivation along contours, and buffer zones - have a neutral or beneficial impact on nitrate loss. An exception is ploughing, which if carried out in early autumn tends to increase leaching if the soil is not frozen. Another exception follows the conversion of conventional to no till practices. In the USA, where no till is commonly recommended as a conservation measure to reduce erosion, conversion to no till was followed by a decrease in soil, total $\mathrm{N}$ and total $\mathrm{P}$ loss in surface runoff but an increase in nitrate leaching and AAP transport (Sharpley and Smith 1994).

Nitrogen and $\mathrm{P}$ management strategies may differ because $\mathrm{N}$ losses can occur from any location in a catchment, while areas prone to surface runoff contribute most to P loss. Hence, for $\mathrm{N}$, remedial strategies may be applied to the whole catchment, whereas the most effective P strategy would be to apply simple measures to the whole catchment to avoid excessive nutrient buildup, and thereby limit losses in subsurface flow, and more stringent measures to the most vulnerable sites to minimise loss of $\mathrm{P}$ in surface runoff.

These positive and negative impacts of conservation practices on resultant water quality should be considered in the development of sound remedial measures. Clearly, a technically sound framework must be developed that includes critical sources of $\mathrm{N}$ and $\mathrm{P}$ export from agricultural catchments so that optimal strategies at farm and catchment scales can be implemented to best manage both $\mathrm{N}$ and $\mathrm{P}$.

\section{Conclusions}

Issues facing agronomic and environmental $\mathrm{P}$ management in agricultural systems are similar in most developed countries. Specialised farming systems within and between these countries have tended to dismantle natural $\mathrm{P}$ cycles, resulting in an imbalanced flow of $\mathrm{P}$ from areas of fertiliser manufacture and grain production to areas of intensive crop and livestock operations. As a result, localised areas of high soil $\mathrm{P}$ can occur near areas of low soil P fertility. In lessdeveloped countries, however, socio-economic constraints generally limit $\mathrm{P}$ use such that many soils are still deficient in $\mathrm{P}$ with respect to that needed for crop production.

Many farm plans addressing $\mathrm{P}$ management assume that if erosion is controlled through soil conservation measures, so will $\mathrm{P}$ losses. Less attention has been directed to a source-based management of $\mathrm{P}$ at field, farm or catchment scales. As a result, soil $\mathrm{P}$ has generally increased in localised areas of intensive crop and livestock production, and increased losses of $\mathrm{P}$ in surface runoff and subsurface flow water are more frequently noted.

Although the relationship between soil and mobilised $\mathrm{P}$ has not been quantified over wide areas, it is clear that the potential for P loss in surface runoff and subsurface flow, and thereby, accelerated eutrophication, increases as soil $\mathrm{P}$ accumulates. Unfortunately, soil $\mathrm{P}$ reduction via crop removal is slow; levels will be elevated for several years after application has ceased. Also, chemical amendments such as alum, fly ash, gypsum and iron compounds reduce the solubility of soil P, not total amounts, and are thus only temporary measures. To a certain extent, these concerns have not been addressed because managing agricultural inputs and outputs of $\mathrm{P}$ is often much more costly and restrictive to a farmer than is general $\mathrm{N}$ management. As a result, $\mathrm{N}$ continues to drive manure management decisions and exacerbates the build-up of soil P.

It is often too simplistic to use threshold or change-point soil $\mathrm{P}$ levels as the sole criterion to guide $\mathrm{P}$ management and $\mathrm{P}$ applications. These values will have little meaning unless they are used in conjunction with an assessment of a site's potential to mobilise $\mathrm{P}$ in surface runoff, erosion and subsurface flow. Thus, preventing $\mathrm{P}$ loss should take on the added dimension of defining, targeting and remediating source areas of $\mathrm{P}$ that combine high soil $\mathrm{P}$ levels with high erosion and surface runoff potentials. As a result, differing 


\section{AGRICULTURAL AND FOOD SCIENCE IN FINLAND}

\section{Seminar in honour of the 100th anniversary of MTT}

levels of management may be suggested for different areas of a catchment, an approach to land management which will have to be addressed by action agencies. Without incorporation of source area perspectives to target application of $\mathrm{P}$ fertility, surface runoff and erosion control technology, conventionally applied remediations may not produce the desired results and may prove to be inefficient and non-cost effective.

Efforts to increase our understanding of $\mathrm{P}$ cycling in terrestrial ecosystems and develop technically sound, defensible remedial strategies that minimise P loss from agricultural land will require interdisciplinary research involving soil scientists, hydrologists, agronomists, limnologists and animal scientists. As importantly, development of guidelines to implement such strategies will also require consideration of the socio-economic and political impacts of any management change on both rural and urban communities, and the mechanisms by which change can be achieved in a diverse and dispersed community of land-users.

\section{References}

Barber, S.A. 1979. Soil phosphorus after 25 years of cropping with five rates of phosphorus application. Communications in Soil Science and Plant Analysis 10: 1459-1468.

Beegle, D.B. 1996. Soil fertility management. In: Serotkin, N. (ed.), The Agronomy Guide, 1997- 1998. Publications Distribution Center, Penn State Univ., University Park, Pennsylvania. p. 17-40.

Breeuwsma, A. \& Silva, S. 1992. Phosphorus fertilization and environmental effects in The Netherlands and the Po region (Italy). Report 57. Agric. Res. Dep. The Winand Staring Centre for Integrated Land, Soil and Water Research. Wageningen, The Netherlands. $39 \mathrm{p}$.

Boström, B., Persson, G. \& Broberg, B. 1988. Bioavailability of different phosphorus forms in freshwater systems. Hydrobiologia 170: 133-155.

Bottcher, A.B., Tremwell, T. \& Campbell, K.L. 1995. Best management practices for water quality improvement in the Lake Okeectiobee Watershed. Ecological Engineering 5: 341-356.

Bremner, J.M. \& Mulvaney, C.S. 1982. Nitrogen - total. In: Page, A.L. et al. (eds.). Methods of soil analysis, Part 2. 2nd ed. Agronomy 9. Am. Soc. Agron., Madison, WI. p. 595-624.

Chesapeake Bay Program. 1995. The state of the Chesapeake Bay, 1995. U.S. Govt. Print. Office, Washington, DC. 65 p.

Dils, R.M. \&Heathwaite, A.L. 1996. Phosphorus fractionation in hillslope hydrological pathwways contributing to agricultural runoff. In: Anderson, M. \& Brookes, S. (eds.). Advances in Hillslope Processes, John Wiley and Sons, Chichester. p. 229-252.

Eck, H.V. \& Stewart, B.A. 1995. Manure. In: Rechcigl, J.E. (ed.). Environmental Aspects of Soil Amendments. Lewis Publishers, Boca Raton, FL. p. 169-198.

Ewards, W.M. \& Owens, L.B. 1991. Large storm effects on total soil erosion. Journal of Soil and Water Conservation 46: 75-77.

Ekholm, P. 1994. Bioavailability of phosphorus in agriculturally loaded rivers in southern Finland. Hydrobiologia 287:179-194.

Gilbertson, C.B., Norstadt, F.A., Mathers, A.C., Holt, R.F., Barnett, A.P., McCalla, T.M., Onstad, C.A. \& Young, R.A. 1979. Animal waste utilization on cropland and pastureland - A manual for evaluating agronomic and environmental effects. U.S. Environ. Prot. Agency and USDA, U.S. EPA Rep. No. EPA 600/2-79-059 and USDA Rep. No. URR 6. U.S. Govt. Printing Off., Washington, D.C. 135 p.

Gburek, W.L., Sharpley, A.N. \& Pionke, H.B. 1996. Identification of critical sources for phosphorus export from agricultural catchments. In: Anderson, M.G. \& Brooks, S.M. (eds.). Advances in Hillslope processes. J. Wiley, Chichester, England. p. 263-282.

Hall, F.R. 1968. Baseflow recessions - A review. Water Resources Research 4: 973-983.

Haygarth, P.M. \& Karvis, S.C. 1997. Soil derived phosphorus in surface runoff from grazed grassland lysimeters. Water Research 11: 140-148.

Heathwaite, A.L. 1997. Sources and pathways of phosphorus loss from agriculture. In: Tunney, $\mathrm{H}$. et al. (eds.). Phosphorus Loss to Water From Agriculture, C.A.B. International, UK. p. 205-224.

- \& Johnes, P.J. 1996. The contribution of nitrogen species and phosphorus fractions to stream water quality in agricultural catchments. Hydrologic Processes 10: 971-983.

- , Haygarth, P.M. \& Dils, R.M. Pathways of phosphorus transport. Proceedings of the Chesapeake Research Consortium meeting on Agricultural Phosphorus in the Chesapeake Bay Watershed: status and trends. 6-8 April 1998, Chesapeake Research Consortium Publication. (in press). 


\section{AGRICULTURAL AND FOOD SCIENCE IN FINLAND}

Vol. 7 (1998): 297-314.

Heatwole, C.D., Bottcher, A.B. \& Baldwin, L.B. 1987. Modeling cost-effectiveness of agricultural nonpoint pollution abatement programs in two Florida basins. Water Resources Bulletin 23: 127-131.

Heckrath, G., Brookes, P.C., Poulton, P.R. \& Goulding, K.W.T. 1995. Phosphorus leaching from soils containing different phosphorus concentrations in the Broadbalk experiment. Journal of Environmental Quality 24: 904-910.

HELCOM 1993. First assessment of the state of the coastal waters of the Baltic Sea - Baltic Marine Environment Protection Commission - Helsinki Commission. Baltic Sea Environment Proc. No. 54. 155 p.

Isermann, K. 1991. Share of agriculture in nitrogen and phosphorus emissions into the surface waters of Western Europe against the background of their eutrophication. Fertilizer Research 26: 253-269.

Kauppi, L., Pietiläinen, O.-P. \& Knuuttila, S. 1993. Impacts of agricultural nutrient loading in Finnish watercourses. Water Science Technology 28: 461-471.

Kotak, B.G., Kenefick, S.L., Fritz, D.L., Rousseaux, C.G., Prepas, E.E. \& Hrudey, S.E. 1993. Occurrence and toxicological evaluation of cyanobacterial toxins in Alberta lakes and farm dugouts. Water Research 27: 495-506.

Krogstad, T. \& Lovstad, O. 1991. Available soil phosphorus for planktonic blue-green algae in eutrophic lake water samples. Archiv fuer Hydrobiologie 122: 117128.

Kronvang, B. \& Svendsen, L.M. 1991. Phosphorus supply to the soil - freshwater environment in the Nordic countries. In: Svendsen, L.M. \& Kronvang, B. (eds.). Phosphorus in the Nordic countries - Methods, bioavailability, effects and measures. Nordisk Ministerrád, Kobenhaven Nord 47, Denmark. p. 101-108.

Lanyon, L.E. \& Thompson, P.B. 1996. Changing emphasis of farm production. In: Salis, M. \& Popow, J. (eds.). Animal agriculture and the environment: Nutrients, pathogens, and community relations. Northeast Regional Agricultural Engineering Service, Ithaca, New York. p. 15-23.

Lawton, L.A. \& Codd, G.A. 1991. Cyanobacterial (bluegreen algae) toxins and their significance in UK and European waters. Journal of Institute Water Environment Management 5: 460-465.

MAFF 1991. Code of Good Agricultural Practice for the Protection of Water. Ministry of Agriculture, Fisheries and Food, HMSO, London, England. 80 p.

- 1994. Fertilizer recommendations for agricultural and horticultural crops. Ministry of Agriculture, Fisheries, and Food, Reference Book 209. HMSO, London, England. 48 p.

Meals, D.W. 1993. Assessing nonpoint phosphorus control in the LaPlatte River watershed. Lake and Reservoir Management 7: 197-207.

Mehlich, A. 1984. Mehlich 3 soil test extractant: A modification of Mehlich 2 extractant. Communications in Soil Science Plant Analysis 15: 1409-1416.

Ministry of the Environment 1988. Water protection program until 1995 in Finland. Ministry of Environment, Series B 12/1988. Helsinki, Finland. 40 p.

Moore, P.A., Jr. \& Miller, D.M. 1994. Decreasing phos- phorus solubility in poultry litter with aluminum, calcium and iron amendments. Journal of Environmental Quality 23: 325-330.

Morse, D., Head, H.H., Wilcox, C.J., van Horn, H.H., Hissem, C.D. \& Harris, B., Jr. 1992. Effects of concentration of dietary phosphorus on amount and route of excretion. Journal Dairy Science 75: 3039-3045.

Murphy, J. \& Riley, J.P. 1962. A modified single solution method for determination of phosphate in natural waters. Analytica Chimica Acta 27: 31-36.

National Research Council 1993. Soil and water quality: An agenda for agriculture. National Academy Press, Washington, DC. $516 \mathrm{p}$.

Pietiläinen, O.-P. \& Rekolainen, S. 1991. Dissolved reactive and total phosphorus load from agricultural and forested basins to surface waters in Finland. Aqua Fennica 21: 127-136.

Pionke, H.B., Gburek, W.J., Sharpley, A.N. \& Zollweg, J.A. 1997. Hydrologic and chemical controls on phosphorus loss from catchments. In: Tunney, H. (ed.). Phosphorus loss to water from agriculture. CAB International Press, Cambridge, England. p. 225-242.

Prato, T. \& Wu, S. 1991. Erosion, sediment, and economic effects of conservation compliance in an agricultural watershed. Journal Soil Water Conservation 46: 211-214.

Rekolainen, S. 1993. Assessment and mitigation of agricultural water pollution. Publications of the Water and Environment Institute, no 12. National Board of Waters and the Environment, Helsinki, Finland. 34 p.

- 1997. Contribution of agriculture to the phosphorus in surface waters in Finland and measures to reduce it. In: Tunney, $\mathrm{H}$. et al. (eds.). Phosphorus loss from soil to water. CAB International Press, Cambridge, England. p. 389-391.

- , Ekholm, P., Ulen, B. \& Gustafson, A. 1997. Phosphorus losses from agriculture to surface waters in the Nordic countries. In: Tunney, H. et al. (eds.). Phosphorus loss from soil to water. CAB International Press, Cambridge, England. p. 77-93.

-, Kauppi, L. \& Turtola, E. 1992. Agriculture and the state of waters. Final report of the MAVERO-project. Ministry of Agriculture and Forestry. Luonnonvarajulkaisuja 15, Helsinki, Finland. $61 \mathrm{p}$.

Schindler, D.W. 1977. Evolution of phosphorus limitation in lakes. Science 195: 260-262.

Sharpley, A.N. 1985. Depth of surface soil-runoff interaction as affected by rainfall, soil slope, and management. Soil Science Society of America Journal 49: 1010-1015.

- 1993. Assessing phosphorus bioavailability in agricultural soils and runoff. Fertilizer Research 36: 259272.

- , Chapra, S.C., Wedepohl, R., Sims, J.T., Daniel, T.C. \& Reddy, K.R. 1994. Managing agricultural phosphorus for the protection of surface waters: Issues and options. Journal of Environmental Quality 23: 437451.

-, Daniel, T.C., Sims, J.T. \& Pote, D.H. 1996. Determining environmentally sound soil phosphorus levels. Journal of Soil and Water Conservation 51: 160 166. 


\title{
AGRICULTURAL AND FOOD SCIENCE IN FINLAND
}

Seminar in honour of the 100th anniversary of MTT

- \& Rekolainen, S. 1997. Phosphorus in agriculture and its environmental implications. In: Tunney, $\mathrm{H}$. et al. (eds.). Phosphorus loss from soil to water. CAB International Press, Cambridge, England. p. 1-54.

- \& Smith, S.J. 1994. Wheat tillage and water quality in the Southern Plains. Soil Tillage Research 30: 3338.

- , Tillman, R.W. \& Syers, J.K. 1977. Use of laboratory extraction data to predict losses of dissolved inorganic phosphate in surface runoff and tile drainage. Journal of Environmental Quality 6: 33-36.

Shreve, B.R., Moore, Jr., P.A., Daniel, T.C., Edwards, D.M. \& Miller, D.M. 1995. Reduction of phosphorus in runoff from field-applied poultry litter using chemical amendments. Journal of Environmental Quality 24: 106-111.

Sibbesen, E. \& Sharpley, A.N. 1997. Setting and justifying upper critical limits for phosphorus in soils. In: Tunney, $\mathrm{H}$. et al. (eds.). Phosphorus loss to water from agriculture. CAB International Press, Cambridge, England. p. 151-176.

Smith, S.J., Sharpley, A.N., Williams, J.R., Berg, W.A. \& Coleman, G.A. 1991. Sediment-nutrient transport during severe storms. In: Fan, S.S. \& Kuo, Y.H. (eds.). Fifth Interagency Sedimentation Conference. March 1991, Las Vegas, NV. Federal Energy Regulatory
Commission, Washington, DC. p. 48-55.

Thomann, R.V. \& Mueller, J.A. 1987. Principles of surface water quality modeling and control. Harper Collins Publ. Inc., New York, NY. 644 p.

USDA 1989. Fact book of agriculture. Misc. Publ. No. 1063, Office of Public Affairs, Washington, DC. p. 17.

USEPA. 1996. Environmental indicators of water quality in the United States. EPA 841-R-96-002. USEPA, Office of Water (4503F), U.S. Govt. Printing Office, Washington, DC. 25 p.

Wadman, W.P., Sluijsmans, C.M.J. \& De La Lande Cremer, L.C.N. 1987. Value of animal manures: changes in perception. In: Van der Meer, H.G. (ed.). Animal Manure on Grassland and Fodder Crops, Martinus Nijhoff Publishers, Dordrecht, The Netherlands.

Withers, P.J.A. 1996. Phosphorus cycling in UK agriculture and implications for water quality. Soil Use and Management 12: 221.

- 1998. New results on P loss. MAFF Environmental protection Newsletter 3: 7 .

Yli-Halla, M., Hartikainen, H., Ekholm, P., Turtola, E., Puustinen, M. \& Kallio, K. 1995. Assessment of soluble phosphorus load in surface runoff by soil analyses. Agricultural Ecosystems Environment 56: 5362.

\section{SELOSTUS}

\section{Maatalous, fosfori ja veden laatu: alkuperä, kulkeutuminen ja vesistökuormituksen hallinta}

\author{
Andrew Sharpley, William Gburek ja Louise Heathwaite \\ USDA-ARS, Pasture Systems and Watershed Management Research Laboratory, \\ USA ja University of Sheffield, Englanti
}

Veteen joutuvan fosforin määrä säätelee makeiden vesien rehevöitymistä. Maatalousvaltaiselta valumaalueelta tulevan fosforin alkuperää selvitettiin maankäytöltään vaihtelevalla alueella Pennsylvaniassa, USA:ssa tutkimalla valuma-alueen hydrologiaa ja maan fosforipitoisuutta. Alueen 39,5 ha:sta $30 \%$ oli metsää, $50 \%$ peltoa ja $20 \%$ laidunta. Mehlich-3 -menetelmällä määritetty maan fosforipitoisuus oli 7$788 \mathrm{mg} \mathrm{kg}^{-1}$. Metsäalueiden maan fosforipitoisuus oli pieni $\left(<30 \mathrm{mg} \mathrm{kg}^{-1}\right)$, laitumilla mitatut arvot vaihtelivat $100-200 \mathrm{mg} \mathrm{kg}^{-1}$ ja väkilannoitteita ja lantaa saa- neilla vilja- ja soijapelloilla fosforipitoisuudet ylittivät usein $200 \mathrm{mg} \mathrm{kg}^{-1}$. Alle 60 metriä laskuojasta olevan maan fosforipitoisuus näytti säätelevän ojaveden fosforipitoisuutta enemmän kuin koko valuma-alueen maan fosforipitoisuus. Viljelytekniset vesiensuojelutoimet tulisikin kohdentaa valuma-alueen tähän osaan, jolla on suurin vaikutus alueelta lähtevän valumaveden fosforipitoisuuteen. Maatalousmaalta tulevaa fosforikuormitusta voidaan säädellä rajoittamalla maahan lisättävän fosforin määrää ja vähentämällä eroosiota ja pintavaluntaa. 